\title{
ANALISIS PENDAPATAN DAN TINGKAT KESEJAHTERAAN RUMAH TANGGA PETANI (KASUS PETANI PADI ORGANIK DAN ANORGANIK DI KECAMATAN PRINGSEWU DAN KECAMATAN PARDASUKA, KABUPATEN PRINGSEWU)
}

\author{
(Analysis of Income and Household Welfare: Case of Organic and Inorganic Rice Farming in Pringsewu \\ and Pardasuka Sub-District, Pringsewu Regency)
}

Ayu Triana, Dwi Haryono, Tubagus Hasanuddin

\begin{abstract}
Jurusan Agribisnis, Fakultas Pertanian, Universitas Lampung, Jl. Prof. Dr. Soemantri Brojonegoro No. 1 Bandar Lampung 35141,e-mail: dwi.haryono@fp.unila.ac.id
\end{abstract}

\begin{abstract}
This research aims to analyze the level of income and welfare of organic and inorganic rice farmers households in Pringsewu and Pardasuka Sub-District. This research used a case study method in Pringsewu and Pardasuka Sub-District, Pringsewu Regency purposively with consideration that the area is a regional pioneer of organic rice farming in Lampung Province and has obtained SNI certification from the government. The total samples were 37 farmers consisted of 17 organic rice farmers and 20 inorganic rice farmers. The data were collected in April-June 2018 and analyzed by farm income analysis, household income analysis, and welfare analysis based on BPS's criteria (2014). The results showed that the average household income of organic and inorganic rice farmers in Pringsewu and Pardasuka Sub-Districts are IDR 21,520,505.88 per year and IDR18,785,344.38 per year. Based on BPS's criteria, as many as $88.24 \%$ and $70 \%$ households of organic and inorganic rice farmers are included in the already prosperous category
\end{abstract}

Key words: household welfare, inorganic rice, income, organic rice

\section{PENDAHULUAN}

Subsektor tanaman pangan merupakan salah satu subsektor pertanian yang memiliki peran penting karena subsektor ini menghasilkan bahan pangan untuk kelangsungan hidup manusia, salah satunya padi sebagai komoditi penghasil beras dan sebagai makanan pokok masyarakat Indonesia. Produksi tanaman padi di Provinsi Lampung terus mengalami peningkatan dalam kurun waktu tahun 2011-2015. Kenaikan produksi padi juga diiringi dengan penambahan luas panen padi dan mencapai produksi tertinggi pada tahun 2015 sebesar 3.641.895 ton dengan produktivitas sebesar 5.149 ton/ha (BPS 2016).

Meskipun produktivitas padi terus meningkat, apabila dalam pembudidayaan padi masih menggunakan cara konvensional dan menggunakan bahan-bahan kimia seperti pupuk dan pestisida kimia, maka dikhawatirkan akan menimbulkan permasalahan baru yakni berkurangnya bahan-bahan organik tanah yang nantinya akan mempengaruhi produktivitas padi. Selain menurunkan produktivitas tanaman, bahanbahan kimia tersebut ternyata menimbulkan efek negatif terhadap kesehatan manusia. Untuk mengatasi masalah tersebut diperlukan cara lain dalam pembudidayaan tanaman padi, yakni salah satunya dengan cara pertanian organik.

Pertanian organik merupakan kegiatan bercocok tanam yang akrab dengan lingkungan, berusaha meminimalkan dampak negatif bagi alam sekitar. Pertanian organik makin banyak diterapkan pada beberapa komoditi pertanian. Salah satu komoditi tersebut adalah padi. Padi merupakan komoditi penghasil beras dan sebagai bahan makanan pokok sebagian besar penduduk Indonesia. Pertanian organik memberikan dampak yang baik bagi kesejahteraan kehidupan petani, karena selain harga cukup tinggi, kualitasnya juga bermutu tinggi (Nurjayanti et al 2016).

Provinsi Lampung merupakan salah satu provinsi di Indonesia yang mengusahakan budidaya padi organik dan anorganik. Tiga kabupaten yang membudidayakan padi organik yaitu Kabupaten Tanggamus, Lampung Tengah, dan Pringsewu dengan luas lahan keseluruhan sebesar 32,03 ha. Kabupaten Pringsewu memiliki tingkat produktivitas padi organik tertinggi di Provinsi Lampung yaitu mencapai 6,2 ton/ha (Dinas Pertanian Provinsi Lampung 2016).

Upaya peningkatan pendapatan petani secara nyata tidak selalu diikuti dengan peningkatan 
kesejahteraan petani. Hal ini karena keberhasilan usaha tersebut juga tidak terlepas dari peran pemerintah dalam hal pendampingan melalui kegiatan penyuluhan untuk meningkatkan wawasan dan pengetahuan petani, distribusi pupuk bersubsidi, peran pemerintah dalam menjaga kestabilan harga, dan lain sebagainya. Perkembangan kebutuhan hidup manusia yang terdiri dari kebutuhan primer, sekunder, dan tersier dapat ditentukan oleh tingkat pendapatan rumah tangga tersebut, karena pada saat harga kebutuhan meningkat, maka kesejahteraan relatif akan menurun (Murdani et al 2015).

Terdapat tiga kecamatan di Kabupaten Pringsewu yang mengusahakan budidaya padi organik, yaitu Kecamatan Pringsewu, Pagelaran, dan Pardasuka. Satu-satunya desa di Kabupaten Pringsewu yang memiliki kelompok tani bersertifikat padi organik adalah Desa Pajaresuk, sedangkan Desa Pujodadi di Kecamatan Pardasuka merupakan salah satu desa binaan baru yang mengusahakan usahatani padi organik.

Petani di Kecamatan Pringsewu dan Pardasuka sudah mulai menerapkan usahatani secara organik, tetapi masih banyak juga petani yang lebih memilih melakukan budidaya secara anorganik. Berdasarkan hal tersebut, maka perlu dilakukan penelitian mengenai analisis usahatani padi organik dan anorganik untuk mengetahui mana yang lebih menguntungkan antara usahatani padi organik dan usahatani padi anorganik, serta pengaruhnya terhadap kesejahteraan rumah tangga petani padi organik dan anorganik di Kecamatan Pringsewu dan Pardasuka Kabupaten Pringsewu. Hal ini diharapkan dapat menjadi suatu referensi dalam upaya pengentasan kemiskinan dan peningkatan taraf hidup petani.

\section{METODE PENELITIAN}

Penelitian ini dilakukan pada bulan April sampai Juni 2018 di Desa Pajaresuk Kecamatan Pringsewu dan Desa Pujodadi Kecamatan Pardasuka Kabupaten Pringsewu dengan metode penelitian studi kasus. Lokasi penelitian dipilih secara purposive dengan pertimbangan bahwa kedua desa tersebut mewakili daerah yang petaninya membudidayakan tanaman padi organik dan anorganik dan padi yang diproduksi oleh kelompok tani yang berada di Desa Pajaresuk Kecamatan Pringsewu telah mendapatkan sertifikasi dari Indonesian Organic Farming Certification (Inofice), sedangkan Desa Pujodadi merupakan desa binaan baru dari Kelompok Tani Sejahtera

yang juga mengusahakan usahatani padi organik di Kabupaten Pringsewu.

Jumlah responden petani padi organik dan anorganik masing-masing berjumlah 17 dan 20 orang. Penentuan responden dipilih dengan teknik sensus, yaitu mengambil seluruh populasi petani padi organik dan petani padi anorganik yang memiliki sawah yang letaknya berdekatan dengan sawah padi organik. Penggunaan metode sensus didasarkan pada beberapa pertimbangan, yaitu jumlah populasi padi organik di Desa Pajaresuk dan Desa Pujodadi relatif kecil, dapat memperoleh informasi yang lengkap tentang ciri dan sifat populasi petani padi organik, dan dapat menghasilkan gambaran yang lengkap dan dapat dipercaya tentang usahatani padi organik yang dilakukan petani padi organik di lokasi penelitian.

Analisis data yang digunakan adalah analisis kuantitatif dan analisis deskriptif kualitatif. Analisis kuantitatif digunakan untuk mengetahui besarnya produktivitas dan pendapatan rumah tangga petani padi organik dan anorganik, sedangkan analisis deskriptif kualitatif digunakan untuk menggambarkan objek penelitian pada saat sekarang yaitu tingkat kesejahteraan rumah tangga petani padi organik dan anorganik di Desa Pajaresuk Kecamatan Pringsewu dan Desa Pujodadi Kecamatan Pardasuka, Kabupaten Pringsewu. Data yang digunakan dalam penelitian ini adalah data primer dan sekunder. Metode analisis yang digunakan dalam penelitian ini adalah metode analisis tingkat pendapatan usahatani, metode pendapatan rumah tangga, dan tingkat kesejahteraan rumah tangga berdasarkan kriteria BPS (2014).

\section{Analisis Pendapatan Usahatani}

Pendapatan usahatani diperoleh dengan menghitung selisih antara penerimaan yang diterima dari hasil usahatani dengan biaya produksi yang dikeluarkan dalam satu musim tanam. Untuk mengetahui pendapatan usahatani, digunakan rumus Soekartawi (2006):

$\pi=\mathrm{YP}_{\mathrm{y}}-\sum \mathrm{X}_{\mathrm{i}} \mathrm{P}_{\mathrm{xi}}$

Keterangan:

$\begin{array}{ll}\pi & =\text { Keuntungan } \\ \mathrm{Y} & =\text { Produksi } \\ \mathrm{P}_{\mathrm{y}} & =\text { Harga produksi } \\ \mathrm{X}_{\mathrm{i}} & =\text { Faktor produksi, } \mathrm{i}=1,2,3,4, \ldots, \mathrm{n} \\ \mathrm{P}_{\mathrm{xi}} & =\text { Harga faktor produksi }\end{array}$


Alat analisis yang digunakan untuk uji beda pendapatan usahatani padi organik dan anorganik adalah deskriptif kuantitatif. Pengolahan data menggunakan aplikasi SPSS dengan analisis compare means, independent samples $t$ test (uji t). Independent samples $t$ test dilakukan karena data antara variabel yang satu dengan yang lainnya tidak saling berkaitan atau independent.

Uji beda dua sampel bebas merupakan salah satu jenis uji perbedaan dua mean yang digunakan untuk menguji kesamaan rata-rata dua sampel yang saling bebas. Jika sampel yang digunakan untuk membuat kesimpulan berukuran kecil atau sampel kurang dari $30(n<30)$ maka dapat menggunakan ttest untuk menganalisis apakah rata-rata yang diperoleh dari sampel dapat digunakan untuk membuat kesimpulan terhadap populasi. Uji beda digunakan untuk melihat apakah terdapat perbedaan signifikan untuk pendapatan atas biaya tunai dan pendapatan atas biaya total pada usahatani padi organik dan anorganik. Rumus statistik dalam uji beda dua sampel bebas yaitu (Priyatno 2009):

Standar Ragam:

$\sigma^{2}=\frac{\left(n_{1}-1\right) s 1^{2}+\left(n_{2}-1\right) s 2^{2}}{n_{1}+n_{2}-2}$

$\sigma_{\mathrm{x} 1-\mathrm{x} 2}=\sqrt{\frac{\sigma^{2}}{\mathrm{n} 1}}+\frac{\sigma^{2}}{\mathrm{n} 2}$

$\mathrm{t}=\frac{\mathrm{x}_{1}-\mathrm{x}_{2}}{\sigma \mathrm{x}_{1}-\mathrm{x}_{2}}$

Keterangan:

$\mathrm{x}_{1} \quad$ : Jumlah sampel petani padi organik

$\mathrm{x}_{2} \quad$ : Jumlah sampel petani padi anorganik

s : : Standar deviasi

$\mathrm{n}_{1}$ dan $\mathrm{n}_{2} \quad:$ Jumlah populasi

$\sigma \quad$ : Ragam

Kriteria pengambilan keputusan:

1. Jika nilai sig (2-tailed) $>0,1$ maka terima $\mathrm{H}_{0}$ artinya usahatani padi organik dan anorganik tidak memiliki perbedaan rata-rata pendapatan yang signifikan.

2. Jika nilai sig (2-tailed) $<0,1$ maka tolak $\mathrm{H}_{0}$ artinya pendapatan usahatani padi organik dan anorganik memiliki perbedaan rata-rata pendapatan yang signifikan.

\section{Analisis Pendapatan Rumah Tangga}

Pendapatan rumah tangga petani diperoleh dengan cara menjumlahkan pendapatan keluarga yang berasal dari on farm, off farm, dan non farm. Untuk mengetahui pendapatan rumah tangga petani digunakan rumus:

$\mathrm{Prt}=\mathrm{P}_{\text {on farm }}+\mathrm{P}_{\text {off farm }}+\mathrm{P}_{\text {non farm }}$

Keterangan:

Prt = Pendapatan rumah tangga petani

$\mathrm{P}_{\text {on farm }}=$ Pendapatan dari usahatani

$\mathrm{P}_{\text {off farm }}=$ Pendapatan dari bidang pertanian luar usahatani

$\mathrm{P}_{\text {non farm }}=$ Pendapatan dari luar pertanian

\section{Analisis Tingkat Kesejahteraan Rumah Tangga}

Metode analisis untuk mengukur tingkat kesejahteraan petani padi organik menggunakan tujuh indikator BPS (2014) yang meliputi kependudukan, kesehatan dan gizi, pendidikan, ketenagakerjaan, taraf dan pola konsumsi, perumahan dan lingkungan, sosial, dan lain-lain. Tingkat kesejahteraan rumah tangga petani padi organik dan anorganik adalah sebagai berikut:

a. Jika skor antara $7-14$ berarti rumah tangga petani belum sejahtera

b. Jika skor antara $15-21$ berarti rumah tangga petani sejahtera.

Jumlah skor diperoleh dari informasi hasil skor mengenai tujuh indikator BPS (2014). Dari penskoran kemudian dilihat interval skor dari dua kategori klasifikasi di atas, yaitu rumah tangga sejahtera atau belum sejahtera (Canita et al 2017).

\section{HASIL DAN PEMBAHASAN}

\section{Karakteristik Responden Petani Padi Organik dan Anorganik}

Sebanyak $52,94 \%$ responden petani padi organik dan $85 \%$ responden petani padi anorganik berumur antara 46-65 tahun. Hal ini menunjukkan bahwa responden petani padi organik dan anorganik tergolong dalam usia produktif. Pada usia produktif tersebut umumnya tingkat kemauan, kemampuan, dan semangat untuk berusahatani cenderung tinggi (Murdani et al 2015).

Rata-rata tingkat pendidikan responden petani padi organik dan anorganik adalah SMA dengan ratarata persentase sebesar $35,15 \%$. Selain memperoleh pendidikan formal, baik petani padi organik maupun anorganik juga sering mengikuti pendidikan non formal berupa pelatihan dan penyuluhan mengenai cara-cara berusahatani yang baik yang diselenggarakan oleh dinas-dinas maupun instansi terkait. 
Seluruh responden petani padi organik memiliki pengalaman usahatani di bawah sepuluh tahun. Responden petani padi anorganik memiliki pengalaman usahatani berkisar antara 31 sampai 40 tahun dengan persentase 55\%. Semakin lama pengalaman usahatani yang dimiliki petani responden maka semakin terampil dalam mengelola usahataninya.

Responden petani padi organik dan anorganik memiliki jumlah tanggungan keluarga berkisar antara tiga sampai empat orang dengan persentase masing-masing sebesar $52,94 \%$ dan $45 \%$. Jumlah tanggungan keluarga yang banyak akan menggambarkan besarnya biaya hidup yang harus dikeluarkan dalam memenuhi kebutuhan keluarga.

Sebanyak $41,18 \%$ responden petani padi organik dan $50 \%$ responden petani padi anorganik tidak memiliki pekerjaan sampingan selain dari usahatani padi. Hal ini disebabkan oleh para petani lebih cenderung untuk memfokuskan pekerjaannya di usahatani padi dan menjadikan usahatani padi menjadi satu-satunya sumber pendapatan rumah tangga mereka.

Sebanyak $94,12 \%$ responden petani padi organik dan $100 \%$ responden petani padi anorganik adalah petani gurem yang memiliki luas lahan padi organik dan anorganik berkisar antara 0,25 sampai 2 ha. Persentase status kepemilikan lahan padi organik adalah $100 \%$ milik sendiri, sedangkan persentase status kepemilikan lahan padi anorganik adalah $90 \%$ milik sendiri dan sisanya sebesar $10 \%$ adalah lahan sewa.

\section{Pola Budidaya Padi Organik dan Anorganik}

Padi organik merupakan salah satu komoditas unggulan yang diusahakan oleh petani di Desa Pajaresuk Kecamatan Pringsewu dan Desa Pujodadi Kecamatan Pardasuka. Padi organik merupakan padi yang proses budidayanya tidak menggunakan pupuk kimia maupun pestisida kimia. Padi organik dan anorganik di daerah penelitian dalam satu tahunnya ditanam sebanyak dua tanam, yaitu musim tanam pertama (rendeng) yang dimulai pada Januari dan musim tanam dua (gadu) yang dimulai pada Mei. Berdasarkan penelitian, terdapat beberapa perbedaan antara budidaya padi organik dan anorganik dikarenakan penggunaan input dan sistem budidaya yang berbeda antara usahatani padi organik maupun usahatani padi anorganik. Berikut ini disajikan beberapa perbedaan antara masing-masing usahatani pada Tabel 1.

Tabel 1. Perbedaan sistem budidaya padi organik dan anorganik

\begin{tabular}{|c|c|c|c|}
\hline No. & Komponen & Padi Organik & $\begin{array}{c}\text { Padi } \\
\text { Anorganik }\end{array}$ \\
\hline 1. & $\begin{array}{l}\text { Kebutuhan } \\
\text { benih }\end{array}$ & $5-7 \mathrm{~kg} / \mathrm{ha}$ & $30-40 \mathrm{~kg} / \mathrm{ha}$ \\
\hline 2. & $\begin{array}{l}\text { Pengujian } \\
\text { benih }\end{array}$ & $\begin{array}{l}\text { Dilakukan } \\
\text { pengujian }\end{array}$ & $\begin{array}{l}\text { Tidak } \\
\text { dilakukan }\end{array}$ \\
\hline 3. & $\begin{array}{l}\text { Umur } \\
\text { persemaian }\end{array}$ & $7-10 \mathrm{HSS}$ & $20-30 \mathrm{HSS}$ \\
\hline 4. & $\begin{array}{l}\text { Pengolahan } \\
\text { tanah }\end{array}$ & $\begin{array}{l}3 \text { kali (struktur } \\
\text { lumpur dan } \\
\text { rata) }\end{array}$ & $\begin{array}{l}2-3 \text { kali } \\
\text { (struktur } \\
\text { lumpur) }\end{array}$ \\
\hline 5. & $\begin{array}{l}\text { Jumlah } \\
\text { tanam/lubang }\end{array}$ & 1 pohon/lubang & $\begin{array}{l}\text { Rata-rata } 5 \\
\text { pohon }\end{array}$ \\
\hline 6. & $\begin{array}{l}\text { Posisi akar } \\
\text { waktu tanam }\end{array}$ & $\begin{array}{l}\text { Posisi akar } \\
\text { horizontal (L) }\end{array}$ & Tidak teratur \\
\hline 7. & Pengairan & $\begin{array}{l}\text { Tidak digenangi } \\
\text { hanya lembab, } \\
\text { disesuaikan }\end{array}$ & $\begin{array}{l}\text { Terus } \\
\text { digenangi }\end{array}$ \\
\hline 8. & Pemupukan & $\begin{array}{l}\text { Hanya pupuk } \\
\text { organik }\end{array}$ & $\begin{array}{l}\text { Mengutamaka } \\
\mathrm{n} \text { pupuk kimia }\end{array}$ \\
\hline 9. & Penyiangan & $\begin{array}{l}\text { Diarahkan pada } \\
\text { pengelolaan } \\
\text { perakaran }\end{array}$ & $\begin{array}{l}\text { Diarahkan } \\
\text { pada } \\
\text { pemberantasa } \\
\text { n gulma }\end{array}$ \\
\hline 10. & Rendemen & $60-70 \%$ & $50-60 \%$ \\
\hline
\end{tabular}

\section{Analisis Usahatani}

Analisis usahatani dilakukan untuk melihat penggunaaan input, biaya-biaya, dan pendapatan yang diperoleh petani padi organik maupun anorganik (Nurjayanti et al 2016).

Biaya usahatani diklasifikasikan menjadi dua yaitu biaya tunai dan biaya diperhitungkan. Biaya tunai meliputi biaya penggunaan input seperti benih, pupuk, pestisida, tenaga kerja luar keluarga, irigasi, sewa lahan, dan pajak. Biaya diperhitungkan yaitu biaya dalam usahatani yang tidak dikeluarkan petani. Biaya yang termasuk dalam biaya diperhitungkan, yaitu biaya tenaga kerja dalam keluarga dan biaya penyusutan peralatan.

Berdasarkan Tabel 2, rata-rata biaya padi organik per hektar lebih tinggi dibandingkan dengan padi anorganik. Rata-rata biaya total usahatani padi organik yang dikeluarkan petani dalam dua musim tanam yaitu sebesar Rp11.873.550,16 per hektar, sedangkan rata-rata biaya total pada usahatani padi anorganik yang dikeluarkan petani dalam dua musim tanam yaitu hanya sebesar Rp9.075.462,72 per hektar. 
Biaya yang paling banyak dikeluarkan pada kedua usahatani adalah biaya pupuk dan biaya tenaga kerja luar keluarga. Pupuk yang digunakan pada usahatani padi organik adalah pupuk organik seperti pupuk kandang dan pupuk kompos, sedangkan pupuk yang digunakan pada usahatani padi anorganik adalah pupuk kimia seperti pupuk urea, SP36, phonska, $\mathrm{KCl}, \mathrm{Za}$, dan Petroganik. Pestisida yang digunakan pada usahatani padi organik adalah pestisida organik yang dibuat dari bahan-bahan alami, sedangkan pestisida yang digunakan pada usahatani padi anorganik adalah pestisida kimia seperti Bentan, Firtako, dan Furadan.

Penggunaan tenaga kerja petani responden terdiri dari tenaga kerja dalam keluarga dan tenaga kerja luar keluarga. Penggunaan tenaga kerja usahatani petani padi responden lebih banyak tercurah ke dalam proses pengolahan lahan, pemanenan, dan penanaman. Untuk pekerjaan seperti penyiangan, dan pengendalian HPT biasanya petani cukup menggunakan tenaga kerja dalam keluarga, meskipun beberapa petani juga mempekerjakan buruh secara upah. Untuk proses pengolahan lahan, petani padi responden lebih banyak mencurahkan tenaga kerja dengan penggunaan mesin traktor.

Pada Tabel 2, terlihat bahwa penggunaan benih pada usahatani padi organik jauh lebih rendah dibandingkan dengan usahatani padi anorganik. Hal ini dikarenakan usahatani padi organik hanya memerlukan benih sebanyak lima sampai tujuh $\mathrm{kg}$ per hektar, sedangkan usahatani padi anorganik memerlukan benih sebanyak 30-40 kg per hektar.

Tabel 2. Rata-rata biaya usahatani padi organik dan anorganik di Kecamatan Pringsewu dan Kecamatan Pardasuka Kabupaten Pringsewu tahun 2017

\begin{tabular}{|c|c|c|c|c|}
\hline \multicolumn{5}{|c|}{ Padi Organik } \\
\hline \multirow{2}{*}{ Biaya } & \multicolumn{2}{|c|}{ Per 0,36 ha } & \multicolumn{2}{|c|}{ Per 1 ha } \\
\hline & MT I & MT II & MT I & MT II \\
\hline \multicolumn{5}{|l|}{ I. Biaya Tunai } \\
\hline Benih & $50.482,35$ & $50.482,35$ & $140.228,76$ & $140.228,76$ \\
\hline Pupuk & $1.666 .372,11$ & $1.658 .541,77$ & $4.628 .811,40$ & $4.607 .060,47$ \\
\hline Pestisida & $15.577,42$ & $26.614,46$ & $43.270,62$ & $73.929,07$ \\
\hline TKLK & $2.065 .176,47$ & $1.850 .500,00$ & $5.736 .601,31$ & $5.140 .277,78$ \\
\hline Pengolahan beras & $150.000,00$ & $150.000,00$ & $416.666,67$ & $416.666,67$ \\
\hline Sewa Lahan & 0,00 & 0,00 & 0,00 & 0,00 \\
\hline Irigasi & $117.000,00$ & $117.000,00$ & $325.000,00$ & $325.00,00$ \\
\hline Pajak & $14.794,12$ & $14.794,12$ & $41.094,77$ & $41.094,77$ \\
\hline Total Biaya Tunai & 4.709 .402 .47 & $3.867 .932,70$ & $11.331 .673,52$ & $10.744 .257,51$ \\
\hline \multicolumn{5}{|l|}{ II. Biaya Diperhitungkan } \\
\hline TKDK & $105.441,18$ & $129.705,88$ & $292.892,16$ & $360.294,12$ \\
\hline Penyusutan alat & $183.236,94$ & $183.236,94$ & $508.991,50$ & $508.991,50$ \\
\hline Benih diperhitungkan & 0,00 & $18.823,53$ & 0,00 & $52.287,58$ \\
\hline Total Biaya & $288.678,12$ & $312.942,82$ & $801.883,66$ & $869.285,62$ \\
\hline \multicolumn{5}{|l|}{ Diperhitungkan } \\
\hline III. Total Biaya & 4.368.080,58 & 4.180.875,53 & $12.133 .557,18$ & $11.613 .543,13$ \\
\hline \multicolumn{5}{|c|}{ Padi Anorganik } \\
\hline Biaya & Per $0,54 \mathrm{l}$ & & & \\
\hline \multicolumn{5}{|l|}{ I. Biaya Tunai } \\
\hline Benih & $525.000,00$ & $292.675,00$ & $972.222,22$ & $541.990,74$ \\
\hline Pupuk & 1.387.010,42 & $1.202 .318,33$ & $2.568 .537,81$ & $2.226 .515,43$ \\
\hline Pestisida & $416.332,36$ & $434.746,38$ & $770.985,86$ & $805.085,89$ \\
\hline TKLK & $2.485 .618,75$ & $2.196 .584,38$ & $4.602 .997,69$ & $4.067 .748,84$ \\
\hline Pengolahan beras & 0,00 & 0,00 & 0,00 & 0,00 \\
\hline Sewa Lahan & $75.000,00$ & $75.000,00$ & $138.888,89$ & $138.888,89$ \\
\hline Irigasi & $68.250,00$ & $77.625,00$ & $126.388,89$ & $143.750,00$ \\
\hline Pajak & $12.500,00$ & $12.500,00$ & $23.148,15$ & $23.148,15$ \\
\hline Total Biaya Tunai & $4.969 .711,53$ & $4.291 .449,09$ & $9.203 .169,51$ & 7.947.127,94 \\
\hline \multicolumn{5}{|l|}{ II. Biaya Diperhitungkan } \\
\hline TKDK & $135.000,00$ & $150.375,00$ & $250.000,00$ & $278.472,22$ \\
\hline Penyusutan alat & $127.482,05$ & $127.482,05$ & $236.077,88$ & $236.077,88$ \\
\hline Benih diperhitungkan & 0,00 & 0,00 & 0,00 & 0,00 \\
\hline Total Biaya & $262.482,05$ & $277.857,05$ & $486.077,88$ & $514.550,10$ \\
\hline \multicolumn{5}{|l|}{ Diperhitungkan } \\
\hline III. Total Biaya & $5.232 .193,58$ & $4.569 .306,14$ & $9.689 .247,39$ & $8.461 .678,04$ \\
\hline
\end{tabular}


Pada usahatani padi organik, terdapat biaya pengolahan beras karena hasil akhir yang dijual pada usahatani ini adalah beras yang sudah dikemas, sedangkan usahatani padi anorganik hanya menjual dalam bentuk gabah kering.

\section{Produksi, Penerimaan dan Pendapatan Usahatani Padi Organik dan Anorganik}

Besarnya penerimaan yang diperoleh petani dipengaruhi oleh besarnya jumlah produksi yang. dihasilkan petani dan harga jual yang sesuai. Pada Tabel 3, dijelaskan rata-rata produksi, penerimaan, dan pendapatan usahatani padi organik dan anorganik di Kecamatan Pringsewu dan Kecamatan Pardasuka Kabupaten Pringsewu. Pada usahatani padi organik, hasil akhir yang dijual adalah dalam bentuk beras organik yang sudah dikemas seharga Rp16.000,00 per kg. Pada usahatani padi anorganik, hasil akhir yang dijual adalah gabah kering seharga Rp4.500,00 per kg.

Rata-rata produksi padi pada usahatani padi organik dan anorganik cenderung mengalami penurunan pada musim tanam II. Hal ini dikarenakan banyaknya serangan hama pada musim tanam II mengakibatkan jumlah produksi padi di daerah penelitian menjadi turun dibandingkan dengan musim tanam I. Rata-rata produksi padi organik pada musim I sebesar $1.955,72 \mathrm{~kg}$ per hektar, sedangkan pada musim tanam II sebesar 1.709,64 kg per hektar. Rata-rata produksi padi anorganik pada musim I sebesar $4.809,26 \mathrm{~kg}$ per hektar, sedangkan pada musim tanam II sebesar 3.393,24 kg per hektar.

Produksi beras anorganik lebih tinggi dibandingkan dengan beras organik. Hal tersebut karena penggunaan pupuk kimia yang dapat memberikan pengaruh cepat dalam peningkatan produksi. Pemberian bahan-bahan kimia yang secara terus menerus akan berdampak buruk terhadap kesuburan lahan pertanian dan dalam jangka waktu panjang dan akan menurunkan produksi padi. Produksi beras organik lebih rendah disebabkan penggunaan pupuk kandang dan bahan organik yang memberikan respon yang cukup lama dalam meningkatkan produksi di awal penerapan (Andalas 2018).

Berdasarkan Tabel 3, dapat dilihat bahwa rata-rata penerimaan petani padi organik lebih tinggi dibandingkan dengan padi anorganik. Rata-rata penerimaan padi organik lebih tinggi dilihat dari penerimaan per musim maupun penerimaan per hektar. Rata-rata penerimaan padi organik lebih tinggi karena rata-rata harga jual beras organik lebih tinggi, yaitu sebesar Rp16.000,00 per kg, sedangkan rata-rata harga jual gabah anorganik yaitu Rp4.862,50 per kg.

Tabel 3. Rata-rata produksi, penerimaan dan pendapatan usahatani padi organik dan anorganik

\begin{tabular}{|c|c|c|c|c|}
\hline \multicolumn{5}{|c|}{ Padi Organik } \\
\hline \multirow{2}{*}{ Keterangan } & \multicolumn{2}{|c|}{ Per 0,36 ha } & \multicolumn{2}{|c|}{ Per 1 ha } \\
\hline & MT I & MT II & MT I & MT II \\
\hline Produksi (kg) & 704,06 & 615,47 & $1.955,72$ & $1.709,64$ \\
\hline $\operatorname{Harga}(\mathrm{Rp})^{*}$ & 16.000 & 16.000 & 16.000 & 16.000 \\
\hline Total Biaya Tunai (Rp) & $4.709 .402,47$ & $3.867 .932,70$ & $11.331 .673,52$ & $10.744 .257,51$ \\
\hline Total Biaya (Rp) & $4.368 .080,58$ & $4.180 .875,53$ & $12.133 .557,18$ & $11.613 .543,13$ \\
\hline Penerimaaan (Rp) & $11.264 .960,00$ & $9.847 .520,00$ & $31.291 .520,00$ & $27.354 .240,00$ \\
\hline Pendapatan atas biaya tunai & $6.555 .557,53$ & $5.979 .587,30$ & $19.959 .846,48$ & $16.609 .982,49$ \\
\hline Pendapatan atas biaya total & $6.896 .879,42$ & $5.666 .644,47$ & $19.157 .962,82$ & $15.740 .696,87$ \\
\hline $\mathrm{R} / \mathrm{C}$ atas biaya tunai & 2,39 & 2,55 & 2,39 & 2,55 \\
\hline $\mathrm{R} / \mathrm{C}$ atas biaya total & 2,58 & 2,36 & 2,58 & 2,36 \\
\hline \multicolumn{5}{|c|}{ Padi Anrganik } \\
\hline Keterangan & Per 0,36 & & & \\
\hline Produksi (kg) & $2.597,00$ & $1.832,35$ & $4.809,26$ & $3.393,24$ \\
\hline $\operatorname{Harga}(\mathrm{Rp})^{*}$ & $4.550,00$ & $5.175,00$ & $4.550,00$ & $5.175,00$ \\
\hline Total Biaya Tunai (Rp) & $4.969 .711,53$ & $4.291 .449,09$ & $9.203 .169,51$ & 7.947.127,94 \\
\hline Total Biaya (Rp) & $5.232 .193,58$ & $4.569 .306,14$ & $9.689 .247,39$ & $8.461 .678,04$ \\
\hline Penerimaaan (Rp) & $11.816 .350,00$ & $9.482 .411,25$ & $21.882 .133,00$ & $17.560 .017,00$ \\
\hline Pendapatan atas biaya tunai & $6.846 .638,47$ & $5.190 .962,16$ & $12.678 .963,49$ & $9.612 .889,06$ \\
\hline Pendapatan atas biaya total & $6.584 .156,42$ & $4.913 .105,11$ & $12.192 .885,61$ & $9.098 .338,96$ \\
\hline $\mathrm{R} / \mathrm{C}$ atas biaya tunai & 2,38 & 2,21 & 2,38 & 2,21 \\
\hline $\mathrm{R} / \mathrm{C}$ atas biaya total & 2,26 & 2,08 & 2,26 & 2,08 \\
\hline
\end{tabular}

${ }^{*}$ : Harga untuk padi organik dalam bentuk beras 
Dari hasil penelitian, rata-rata pendapatan atas biaya tunai dan pendapatan atas biaya total pada usahatani padi organik lebih besar dibandingkan dengan usahatani padi anorganik. Rata-rata pendapatan atas biaya tunai dan biaya total pada usahatani padi organik adalah Rp18.824.914,49 per hektar dan Rp17.449.329,85 per hektar. Rata-rata pendapatan atas biaya tunai dan biaya total pada usahatani padi anorganik adalah Rp11.145.926,28 per hektar dan Rp10.645.612,29 per hektar.

Berdasarkan Tabel 3. diketahui bahwa hasil analisis $\mathrm{R} / \mathrm{C}$ ratio atas biaya tunai dan biaya total pada usahatani beras organik dan usahatani padi anorganik $>1$, yang artinya usahatani tersebut menguntungkan. Nilai $\mathrm{R} / \mathrm{C}$ ratio atas biaya tunai usahatani padi organik lebih besar dari $\mathrm{R} / \mathrm{C}$ ratio usahatani padi anorganik. Hal tersebut menunjukkan bahwa usahatani padi organik lebih menguntungkan dibandingkan dengan usahatani padi anorganik.

Nilai R/C atas biaya tunai pada usahatani padi organik pada musim tanam I dan II adalah sebesar 2,39 dan 2,55. Artinya setiap satu rupiah biaya tunai dikeluarkan oleh petani, maka usahatani padi organik menghasilkan tambahan sebesar Rp2,39 dan Rp2,55. Nilai R/C atas biaya total pada usahatani padi organik pada musim tanam I dan II adalah sebesar 2,37 dan 2,12. Artinya setiap satu rupiah biaya total dikeluarkan oleh petani, maka usahatani padi organik menghasilkan tambahan sebesar Rp2,37 dan Rp2,12.

Hasil perhitungan uji beda rata-rata pendapatan usahatani padi organik dan anorganik menggunakan uji t (Independet Samples T test), baik pada musim tanam I maupun musim tanam II diperoleh nilai signifikan $\alpha=$ kurang dari 0,05 yang berarti bahwa terdapat perbedaan yang signifikan terhadap pendapatan usahatani padi organik dan anorganik.

\section{Analisis Pendapatan Rumah Tangga Petani Padi Organik dan Anorganik}

Sumber pendapatan rumah tangga petani padi organik dan anorganik di Kecamatan Pringsewu dan Pardasuka diperoleh dari pendapatan usahatani dari kegiatan budidaya (on farm), kegiatan pertanian di luar usahatani (off farm), dan usaha non pertanian (non farm). Masing-masing sumber pendapatan mempunyai peranan penting yang dapat menunjukkan kemampuan daya dukung sumberdaya alam maupun sumberdaya manusia yang dimiliki (Putri 2013). Dari hasil perhitungan ketiga sumber pendapatan tersebut, diketahui bahwa rata-rata pendapatan rumah tangga petani padi organik sebesar Rp21.520.505,88 per tahun. Rata-rata pendapatan rumah tangga petani padi anorganik sebesar Rp18.785.344,38 per tahun. Rata-rata pendapatan rumah tangga petani padi organik dan anorganik di Kecamatan Pringsewu dan Pardasuka tahun 2017 disajikan pada Tabel 4.

Tabel 4. Rata-rata pendapatan rumah tangga petani padi organik dan anorganik

\begin{tabular}{lrr}
\hline \multirow{2}{*}{$\begin{array}{l}\text { Sumber Pendapatan } \\
\text { Rumah Tangga }\end{array}$} & $\begin{array}{c}\text { Padi Organik } \\
\text { Pendapatan } \\
\text { (Rp) }\end{array}$ & \multicolumn{1}{c}{$\begin{array}{c}\text { Pendi Anorganik } \\
(\mathrm{Rp})\end{array}$} \\
\hline 1. On farm & $13.588 .152,94$ & $11.977 .844,38$ \\
2. On farm non padi & $882.352,94$ & 0,00 \\
2. Off farm & $308.823,53$ & $1.177 .500,00$ \\
3. Non farm & $6.741 .176,47$ & $5.630 .000,00$ \\
\hline Jumlah & $21.520 .505,88$ & $18.785 .344,38$ \\
\hline
\end{tabular}

Jika dilihat pada Tabel 4, pendapatan dari sektor pertanian pada rumah tagga petani padi organik menyumbang pendapatan sebesar lebih dari $68,31 \%$ dari total keseluruhan pendapatan rumah tangga petani padi organik, sedangkan pada rumah tangga petani padi anorganik, pendapatan dari sektor pertanian menyumbang pendapatan sebesar 70,03\% Hal ini menjelaskan bahwa transformasi ekonomi di pedesaan masih tetap menempatkan sektor pertanian sebagai sektor yang memegang peranan penting dalam memberikan peluang kesempatan kerja dan menyumbang peningkatan pendapatan rumah tangga petani (Aprilliani 2016).

\section{Analisis Tingkat Kesejahteraan Rumah Tangga Petani Padi Organik dan Anorganik}

Kesejahteraan merupakan tujuan akhir dari pembangunan suatu negara. Pendapatan merupakan salah satu tolak ukur dari kesejahteraan. Semakin tinggi tingkat pendapatan maka semakin tinggi pula tingkat kesejahteraan rumah tangga tersebut, namun seiring dengan pertambahan jumlah anggota rumah tangga pendapatan yang dihasilkan tidak mampu memenuhi kebutuhan anggota rumah tangga tersebut. Sebaran kesejahteraan rumah tangga petani pada organik dan anorganik secara rinci dapat dilihat pada Tabel 5. 
Tabel 5. Sebaran kesejahteraan rumah tangga petani pada organik dan anorganik

\begin{tabular}{cccc}
\hline \multicolumn{4}{c}{ Petani Padi Organik } \\
\hline Kategori & $\begin{array}{c}\text { Interval } \\
\text { Skor }\end{array}$ & $\begin{array}{c}\text { Jumlah } \\
(\mathrm{RT})\end{array}$ & $\begin{array}{c}\text { Persentase } \\
(\%)\end{array}$ \\
\hline Sudah Sejahtera & $7-14$ & 15,00 & 88,24 \\
Belum Sejahtera & $15-21$ & 2,00 & 11,76 \\
\hline \multicolumn{4}{c}{ Petani Padi Anorganik } \\
\hline Kategori & Interval & Jumlah & Persentase \\
& Skor & (RT) & $(\%)$ \\
\hline Sudah Sejahtera & $7-14$ & 14,00 & 70,00 \\
Belum Sejahtera & $15-21$ & 6,00 & 30,00 \\
\hline
\end{tabular}

Berdasarkan penelitian, rumah tangga petani padi organik memiliki persentase rumah tangga sudah sejahtera lebih besar dibandingkan rumah tangga petani anorganik. Sebanyak $15(88,24 \%)$ rumah tangga petani padi organik termasuk dalam golongan rumah tangga sudah sejahtera, sedangkan sisanya sebanyak dua $(11,76 \%)$ rumah tangga petani padi organik termasuk dalam golongan rumah tangga belum sejahtera. Sementara itu, sebanyak $14(70 \%)$ rumah tangga petani padi anorganik adalah rumah tangga sudah sejahtera, sedangkan sisanya sebanyak enam (30\%) adalah rumah tangga belum sejahtera.

\section{KESIMPULAN}

Rata-rata pendapatan rumah tangga petani padi organik di Kecamatan Pringsewu dan Kecamatan Pardasuka adalah sebesar Rp 21.520.505,88 per tahun. Rata-rata pendapatan rumah tangga petani padi anorganik di Kecamatan Pringsewu dan Kecamatan Pardasuka adalah sebesar Rp18.785.344,38 per tahun. Berdasarkan kriteria Badan Pusat Statistik (2014), sebanyak 15 rumah tangga atau $88,24 \%$ rumah tangga petani padi organik termasuk dalam golongan rumah tangga sudah sejahtera. Sebanyak 15 rumah tangga atau $75 \%$ rumah tangga petani padi anorganik sudah sejahtera, sedangkan sisanya sebanyak lima atau $25 \%$ belum sejahtera.

\section{DAFTAR PUSTAKA}

Andalas MS dan Sudrajat. 2018. Analsis komparatif sistem pertanian padi organik dan anorganik di Desa Catur Kecamatan Sambi Kabupaten Boyolali. JBI, 7(1): 1-10. http://lib.geo.ugm.ac.id/ojs/index.php/jbi/ article/view/907/880. [23 Februari 2019].

Apriliani R. Analisis Pendapatan dan risiko usahatani padi organik dan anorganik di Kabupaten Pringsewu. Skripsi. Fakultas Pertanian. Universitas Lampung.

BPS [Badan Pusat Statistik]. 2014. Indikator Kesejahteraan Rakyat. BPS. Jakarta.

BPS [Badan Pusat Statistik] Provinsi Lampung. 2016. Lampung dalam Angka. BPS Provinsi Lampung. Bandar Lampung.

Canita PL, Haryono D, dan Kasymir E. 2017. Analisis pendapatan dan tingkat kesejahteraan rumah tangga petani pisang di Kecamatan Padang Cermin Kabupaten Pesawaran. JIIA, 5(3): 235-241. http://jurnal.fp.unila.ac.id/index.php/JIA/ article/view/1635/1461. [23 Februari 2019].

Dinas Pertanian Provinsi Lampung. 2016. Luas Lahan dan Produktivitas Padi Organik di Provinsi Lampung. Dinas Pertanian Povinsi Lampung. Bandar Lampung.

Murdani MI, Widjaya S, dan Rosanti N. 2015. Pendapatan dan tingkat kesejahteraan rumah tangga petani padi (Oryza sativa) di Kecamatan Gading Rejo Kabupaten Pringsewu. JIIA, 3(2): 165-172. http://jurnal.fp.unila.ac.id/index.php/JIA/ article/view/1035/940. [5 Desember 2018].

Nurjayanti A, Effendi I, dan Nurmayasari I. 2016. Pendapatan dan manfaat usahatani padi organik di Kabupaten Pringsewu. JIIA, 4(2):126-133. http://jurnal.fp.unila.ac.id/ index.php/JIA/article/view/1229/1126. [3 Desember 2018].

Priyatno D. 2009. 5 Jam Belajar Olah Data dengan SPSS. Andi Offset. Yogyakarta.

Putri TL, Lestari DAH, dan Nugraha A. 2013. Pendapatan dan kesejahteraan petani padi organik peserta sekolah lapang pengelolaan tanaman terpadu (SL-PTT) di Kecamatan Pagelaran Kabupaten Tanggamus. JIIA, 1(3):226-231.http://jurnal.fp.unila.ac.id/ index.php/JIA/article/view/578/540. Januari 2019].

Soekartawi. 2006. Analisis Usahatani. UI-Press. Jakarta.

Sutanto R. 2002. Penerapan Pertanian Organik: Permasyarakatan dan Pengembangannya. Penerbit Kanisius. Yogyakarta. 